\title{
HUBUNGAN DAYA LEDAK OTOT TUNGKAI DAN PANJANG TUNGKAI TERHADAP HASIL MENENDANG BOLA DALAM PERMAINAN SEPAKBOLA PADA MAHASISWA PROGRAM STUDI PENDIDIKAN OLAHRAGA FAKULTAS KEGURUAN DAN ILMU PENDIDIKAN UNIVERSITAS BINA DARMA PALEMBANG
}

\author{
Bayu Hardiyono ${ }^{1}$, Nurkadri $^{2}$, Budiman Agung Pratama $^{3}$
}

\section{Keywords :}

Daya Ledak Otot Tungkai;

Kelentukan Tungkai;

Tendangan Jauh.

\section{Corespondensi Author \\ ${ }^{1}$ Universitas Bina Darma \\ Palembang, \\ bayu.hardiyono@binadarma.ac.id \\ ${ }^{2}$ Universitas Negeri Medan, nurkadri@unimed.ac.id \\ ${ }^{3}$ Universitas Nusantara PGRI \\ Kediri \\ agung10@unpkediri.ac.id}

\author{
Article History \\ Received: Agustus; \\ Reviewed: Agustus; \\ Accepted: September; \\ Published: Oktober
}

\begin{abstract}
ABSTRAK
Penelitian ini bertujuan untuk mengetahui hubungan daya ledak otot tungkai dan panjang tungkai terhadap hasil menendang bola dalam permainan sepakbola. Populasi penelitian ini adalah Atlet sepakbola Fakultas Ilmu Keolahragaan Universitas Negeri Makassar. Sampel yang digunakan sebanyak 30 Atlet, dan teknik pengambilan sampel adalah sampling purposive. Metode pengolahan data menggunakan statistik deskriptif, normalitas data, uji keofisien regresi, dan uji hipotesis dengan uji regresi sederhana dan ganda. Hasil analisis menujukkan bahwa: (1) Ada hubungan yang signifikan daya ledak otot tungkai terhadap hasil menendang bola dalam permainan sepakbola pada mahasiswa Program Studi Pendidikan Olahraga Fakultas Keguruan dan Ilmu Pendidikan Universitas Bina Darma Palembang, terbukti nilai $r=0,747(\rho<a$ 0,05), (2) Ada hubungan yang signifikan panjang tungkai terhadap hasil menendang bola dalam permainan sepakbola pada mahasiswa Jurusan Pendidikan Kepelatihan Olahraga Fakultas Ilmu Keolahragaan Univesitas Negeri Makassar, terbukti nilai $r=0,802\left(P_{\text {valube }}<a 0,05\right)$, dan (3) Ada hubungan yang signifikan antara daya ledak otot tungkai dan panjang tungkai terhadap hasil menendang bola dalam permainan sepakbola pada mahasiswa Program Studi Pendidikan Olahraga Fakultas Keguruan dan Ilmu Pendidikan Universitas Bina Darma Palembang diperoleh nilai $r=0,939\left(P_{\text {valube }}<a\right.$ 0,05).
\end{abstract}

\section{PENDAHULUAN}

Pembinaan sepakbola di perguruan tinggi juga menjadi salah satu faktor utama yang mempengaruhi prestasi olahraga permainan sepakbola, karena pembinaan di perguruan tinggi akan melahirkan pemain-pemain profesional yang dibutuhkan dalam pencapaian prestasi yang maksimal. Banyak perguruan tinggi yang mempunyai tim sepakbola sendiri bahkan ada pula yang menempatkan sepakbola sebagai salah satu syarat seleksi mahasiswa sebelum masuk dalam perguruan tinggi. Program Studi Pendidikan Olahraga Fakultas Keguruan dan Ilmu Pendidikan adalah sebuah fakultas yang berada di Universitas Bina Darma, Palembang dimana Program Studi Pendidikan Olahraga Fakultas Keguruan dan Ilmu Pendidikan memiliki banyak Atlet-atlet berprestasi, namun pada perkembangan Atlet sepakbola 


\section{e-ISSN: 2657-0703 dan p-ISSN: 2085-5389}

Program Studi Pendidikan Olahraga Fakultas Keguruan dan Ilmu Pendidikan, pesepak bolaannya masih banyak kekurangankekurangan, dikarenakan tidak adanya sentuhan, pembinaan atau pelatih. Atlet-atlet yang berada di Program Studi Pendidikan Olahraga Fakultas Keguruan dan Ilmu Pendidikan, hanya mengandalkan latihan setiap 1 pekan 3 kali setiap sore, tetapi tidak ada sentuhan Pelatih, mengakibatkan Atlet hanya sekedar bermain, menendang dan mengejar, tetapi tidak menjuru kepada prestasi. Padahal begitu banyak kompetisi antar liga mahasiswa yang, dimana adanya kompetisi ini atlet-atlet yang berada di Program Studi Pendidikan Olahraga Fakultas Keguruan dan Ilmu Pendidikan bisa ikut serta dalam kompetisi tersebut. Kemudian disamping itu, diadakan pembinaan atau pelatih demi kemajuan pesepakbola di Program Studi Pendidikan Olahraga Fakultas Keguruan dan Ilmu Pendidikan.

Penguasaan keterampilan teknik dasar bagi seorang pemain sepakbola adalah penting, karena sangat berkaitan dengan tujuan permainan sepakbola yaitu melakukan kemammpuan tendangan jauh. Tanpa penguasaan teknik yang memadai maka tujuan permainan sepakbola cenderung tidak akan tercapai. Menendang bola merupakan salah satu teknik yang harus dikuasai oleh seorang pemain sepakbola, karena berdasarkan fungsinya, menendang bola dapat digunakan sebagai cara memberikan (mengoper) bola kepada teman dalam berbagai jarak dan melakukan tendangan jauh. Jika kemampuan menendang bola ini kurang baik maka seorang pemain dapat dikatakan tidak dapat bermain sepakbola dengan baik. Kemudian Sukatamsi (1997:230) menyatakan: Menendang bola merupakan teknik dasar bermain sepakbola yang paling banyak digunakan dalam permainan sepakbola. Kesebelasan sepakbola yang baik adalah suatu kesebelasan sepakbola yang semua pemainnya menguasai teknik dasar menendang bola dengan baik, cepat dan tepat ke arah sasaran, baik teman maupun sasaran dalam membuat gol ke gawang lawan." Karana itu kita harus bisa mengembangkan berbagai variasi tendangan dalam sepakbola dengan latihan mengembangkan tendangan kita bisa menjadi lebih terampil dalam melakukan hasil menendang bola dalam permainan sepakbola.
Perbanyak latihan dengan mengembangkan tendangan dalam sepakbola.

Secara biomekanika, teknik menendang bola dengan tujuan untuk menendang bola sejauh munkin maka harus sesuai dengan hukum gerak sebagai berikut: Untuk mencapai tujuan tendangan, maka tungkai sebagai subjek gerak harus dapat bergerak dengan cepat dan kuat khususnya untuk menendang bola jauh. Daya ledak otot tungkai pempunyai peranan yang sangat penting terhadap keberhasilan dalam melakukan tendangan jauh, karena adanya daya ledak otot tungkai mamberikan kekuatan dan kontraksi tinggi. Kelentukan tungkai sebagai pembantu dalam proses melakukan sebuah gerakan yang dimana kelentukan tungkai sangat menunjang dalam proses melakukan sebuah tendangan jauh, karena posisi pada saat proses melakukan sebuah tendangan di perlukan posisi persendian yang lentur pada sendi lutut, yang akan menunjang dalam proses melakukan sebuh tendangan. Panjang tungkai sangat berperan penting dalam melakukan sebuah tendangan, karena panjang tungkai sebagai pengungkit yang menunjang dalam melakukan sebuah geraka menendang dan dapat menghasilkan sebuah tendangan yang jauh. Hal ini berarti tendangan harus dilakukan dengan gaya yang besar, dan waktu tempuh yang singkat.

Penguasaan teknik dasar merupakan suatu syaraf yang harus dimiliki oleh pemain. Keberhasilan suatu tim dalam setiap pertandingan ditentukan oleh penguasaan teknik dasar, karena dengan penguasaan teknik dasar akan tercipta permainan yang bermutu dan menggunakan teknik yang baik pula. Teknik dasar adalah semua gerakangerakan tanpa bola dan gerakan-gerakan dengan bola yang diperlukan dalam bermain sepakbola, jadi teknik dasar bermain sepakbola adalah merupakan kemampuan untuk melakukan gerakan-gerakan atau mengerjakan sesuatu yang terlepas sama sekali dari pemain sepakbola yang profesional harus menguasai teknik dasar bermain sepakbola terlebih dahulu sebelum bermain dalam permainan sepakbola (Sukatamsi, 1984:33). Teknik dasar yang perlu dimliki oleh pemain sepakbola adalah menendang, menghentikan, menggiring, menyundul, merampas, lemparan ke dalam, dan menjaga gawang (Sucipto dkk, 2000: 17). 


\section{Volume 10 Nomor 3, Oktober 2018}

Permainan sepakbola yang baik memerlukan penguasaan teknik dasar yang baik. Pemain yang memiliki teknik dasar cenderung dapat memainkan sepakbola yang baik pula. Teknik dasar permainan sepakbola ada beberapa macam yaitu menendang bola, menggiring bola, mengontrol bola, menyundul bola, merebut bola, lemparan kedalam, gerak tipu, dan teknik penjaga gawang. Keaneka ragaman teknik dasar tersebut harus dikuasai oleh para pemain (Sukatamsi,1984: 34).

Menendang bola merupakan kegiatan yang paling banyak dilakukan dalan permainan sepakbola. Seorang pemain sepakbola tidak menguasai menendang dengan baik, tidak akan menjadi pemain yang baik. Kesebelasan yang baik adalah yang semua pemainnya menguasai tendangan bola dengan baik, dengan cepat, cermat dan tepat sasaran, sasaran teman maupun dalam membuat gol ke mulut gawang. Fralick (1945:17) menyatakan, "Shooting at the goal is a very important phase of the game."Mengingat tendangan merupakan faktor terpenting dan utama dalam permainan sepakbola maka untuk menjadi pemain yang baik, perlulah pemain mengembangkan kemahiran dalam menendang. Menendang yang baik dalam permainan sepakbola memerlukan kemampuan memperkirakan jarak dan arah mana bola harus dihantarkan. Oleh karena itu, seorang Atlet yang akan menendang bola hendaknya memperkirakan sejauh mana tendangannya dan kearah mana bola yang ditendang akan dituju. (Sukatamsi, 1984: 44). Menendang bola merupakan salah satu karakteristik perminan sepakbola yang paling dominan. Pemain yang memiliki teknik memendang dengan baik akan bermain dengan baik dan efisien. Tujuan menendang bola adalah mengumpan (passing), menembak ke gawang (shooting at the goal), menyapu untuk menggagalkan serangan lawan (sweeping) (Sucipto dkk, 2000:17). Ada beberapa macam dasar tendangan (Sukatamsi, 1984: 47), yaitu: Atas dasar bagian mana dari kaki yang digunakan untuk menendang bola, ada lima bagian kaki yaitu; a) Dengan kurakura kaki penuh, b) Dengan kura-kura kaki bagian dalam, c) Dengan kura-kura kaki bagian luar, d) Dengan ujung kaki, e) Dengan tumit. Atas dasar kegunaan atau fungsi dari tendangan yaitu; a) Untuk memberikan operan bola kepada teman, b) Untuk menembakkan bola kearah mulut gawang lawan, untuk membuat gol kemenangan, c) Untuk membersihkan atau menyapu bola di daerah pertahanan (belakang) langsung ke depan, biasa dilakukan pemain belakang untuk mematahkan serangan lawan, d) Untuk melakukan bermacam-macam tendangan khusus yaitu tendangan bebas, tendangan sudut, tendangan hukuman (penalti). Atas dasar tinggi rendahnya lambungan bola, tendangan dapat dibedakan menjadi tiga macam yaitu ; a) Tendangan bola rendah, bola menggulir datar diatas permukaan tanah sampai setinggi lutut, b) Tendangan bola melambung lurus atau melambung sedang, bola melambung paling rendah setinggi lutut dan paling tinggi setinggi kepala, c) Tendangan bola melambung tinggi, bola melambung paling rendah setinggi kepala. Atas dasar arah putaran dari jalannya bola, tendangan dibedakan menjadi dua macam yaitu ; a) Tendangan lurus (langsung), bola setelah ditendang tidak berputar, sehingga bola melambung lurus dan jalannya kencang. Tenaga tendangan melalui titik pusat bola, b) Tendangan melengkung (slice), bola setelah ditendang berputar kearah yang berlawanan dengan arah tendangan dan arah bola, bila bola melambung setelah sampai puncak akan turun vertikal. Tenaga tendangan tidak melalui titik pusat bola. Tendangan juah merupakan sebuah gerakan kura-kura kaki dalam yang dimana pada saat melakukan sebuah tendangan posisi kaki tumpu diletakkan di samping belakang bola $\pm 30 \mathrm{~cm}$ dengan ujung kaki membuat sudut $40^{\circ}$ dengan garis lurus bola. Kaki tumpu tidak boleh goyang, karena akan mempengaruhi hasil tendangan yang dihasilkan. Selain itu kaki tumpu diusahakan untuk menghadap kesasaran. (Sucipto 2000:21). Prinsip dalam teknik menendang bola jauh dengan kura-kura kaki bagian dalam adalah: (1) Kaki Tumpu, (2) Kaki Ayun , (3) Bagian Bola Yang Ditendang, (4) Sikap Badan, (5) Pandangan Mata, dan (6) Gerak Lanjutan

Daya ledak otot tungkai merupakan suatu unsur-unsur komponen kondisi fisik yaitu kemampuan biomotorik manusia, yang dapat ditingkatkan sampai batas-batas tertentu dengan melakukan latihan-latihan tertentu yang sesuai. Daya ledak otot tungkai adalah suatu kemampuan seorang atlet untuk mengatasi suatu hambatan dengan kecepatan kontraksi yang tinggi. Daya ledak tungkai ini diperlukan dibeberapa gerakan asiklis, 


\section{e-ISSN: 2657-0703 dan p-ISSN: 2085-5389}

misalnya pada mahasiswa Jurusan Pendidikan Kepelatihan Olahraga seperti, tendangan tinggi atau tendangan jauh. Daya ledak otot tungkai merupakan hasil perpaduan dari kekuatan dan kecepatan pada kontraksi otot (Bompa, 1983:231). Daya ledak otot tungkai merupakan salah satu dari komponen gerak yang sangat penting untuk melakukan aktivitas yang sangat berat karena dapat menentukan seberapa kuat Atlet menendang, seberapa jauh Atlet melakuan tendangan, dan lainnya. Daya ledak otot tungkai adalah faktor utama dalam melaksanankan segala macam keterampilan gerak dalam berbagai cabang olahraga. Berdasarkan pada definisi-definisi diatas dapat disimpulkan bahwa dua unsur penting yang menentukan kualitas daya ledak otot tungkai adalah kekuatan dan kecepatan. M. Sajoto (1995:55) menyatakan bahwa daya ledak atau power adalah kemampuan melakukan gerakan mengatasi tahanan dengan suatu kecepatan kontraksi tinggi (eksplosif). Power adalah hasil perkalian kekuatan maksimal (force) dengan waktu pelaksanaan tersebut $(\mathrm{P}=\mathrm{F} \times \mathrm{T})$. Kombinasi antara kekuatan dan kecepatan, diperlihatkan anakanak waktu melakukan lompat jauh, lopatan tanpa awalan, fertiakal jump, dan gerak eksplosif yang lain, yang memerlukan pengetahuan tenaga sepenuhnya, seperti melakukan hasil menendang bola dalam permainan sepakbola. Upaya meningkatkan unsur daya ledak otot tungkai dapat dilakukan dengan cara : a) meningkatkan kekuatan tanpa mengabaikan kecepatan atau menitik beratkan pada kekuatan, b) meningkatkan kecepatan tanpa mengabaikan kekuatan atau menitik beratkan pada kecepatan, c) meningkatkan keduanya sekaligus kekuatan dan kecepatan dilatih secara simultan. Daya ledak otot tungkai mempunyai peranan yang sangat penting terhadap keberhasilan lompat jauh maka awalan dilakukan secepat-cepatnya dan kecepatan tetap dipertahankan sampai pada saat akan melakukan tolakan untuk melompat. Pada saat melakukan tolakan ini diperlukan daya tolakan yang besar untuk mendapatkan hasil lompatan yang lebih jauh. Daya ledak otot tungkai (power) disini diperoleh dari kecepatan lari yang cepat dan tolakan yang kuat dari balok tolakan.

Panjang tungkai adalah seluruh kaki dari pangkal paha ke bawah (Kamus Besar Bahasa Indonesia, 2002:857). Panjang tungkai sebagai bagian dari postur tubuh memiliki hubungan yang sangat erat dalam kaitannya sebagai pengungkit disaat menendang bola. Panjang tungkai sebagai salah satu anggota gerak bahwa memiliki peran penting dalam unjuk kerja olahraga. Sebagai anggota gerak bawah panjang tungkai berfungsi sebagai penopang gerak anggota tubuh bagian atas, serta penentu gerakan baik dalam berjalan, berlari, melompat, maupun menendang. Anggota gerak bawah dikaitkan pada batang tubuh dengan perantara gelang panggul meliputi : a). tulang pangkal paha, b). tulang paha (femur), c). tulang kering (tibia), d). tulang betis (fibula), e). tempurung lutut (patela), f). tulang pangkal kaki (tarsilia), g). tulang telapak kaki (metatarsalia) dan h). ruas jari-jari (phalangus). Otot-otot penggerak tungkai atas, mempunyai selaput pembungkus yang sangat kuat dan disebut fasia lata. (H. Syaefudin, 2006:62).

\section{METODE}

Variabel yang dalam penelitian ini adalah sebagai berikut: Variabel bebas (X) yaitu: daya ledak otot tungkai (X1) dan panjang tungkai (X2), sedangkan variabel terikat adalah hasil tendangan jauh sebagai variabel terikat (Y). Rancangan penelitian yang digunakan yaitu desain korelasional (corelational design). Adapun yang dijadikan populasi dalam penelitian ini adalah mahasiswa Program Studi Pendidikan Olahraga Fakultas Keguruan dan Ilmu Pendidikan Universitas Bina Darma Palembang. Sample yang digunakan adalah mahasiswa Angkatan 2018 Program Studi Pendidikan Olahraga Fakultas Keguruan dan Ilmu Pendidikan Universitas Bina Darma Palembang sebanyak 30 orang, yang diperoleh melalui teknik penarikan dengan cara sampling purposive. Metode pengolahan data menggunakan statistik deskriptif, normalitas data, uji keofisien regresi, dan uji hipotesis dengan uji regresi sederhana dan ganda pada taraf signifikan $95 \%$.

\section{HASIL DAN PEMBAHASAN}

\section{Hasil}

1. Ada hubungan daya ledak otot tungkai terhadap hasil menendang bola dalam permainan sepakbola pada mahasiswa Program Studi Pendidikan Olahraga Fakultas Keguruan dan Ilmu Pendidikan Universitas Bina Darma Palembang. 


\section{Volume 10 Nomor 3, Oktober 2018}

Hipotesis statistic:

$\mathrm{H}_{0}: \rho \mathrm{x}_{1} \mathrm{y}=0$

$\mathrm{H}_{1:}: \rho \mathrm{x}_{1} \mathrm{y} \neq 0$

Kriteria pengujian:

Jika $\rho$ ( Sig. > a 0,05), maka diterima $\mathrm{H}_{0}$

Jika $\rho$ ( Sig. $\leq$ a 0,05$)$, maka $\mathrm{H}_{0}$ ditolak dan

$\mathrm{H}_{1}$ diterima.

Hasil pengujian:

Berdasarkan kriteria pengujian tersebut, maka hasil analisis koefisien regresi daya ledak otot tungka dengan hasil menendang bola dalam permainan sepakbola. Diperoleh nilai $r=0,747(\rho<a 0,05)$, maka diputuskan bahwa $\mathrm{H}_{1}$ diterima, berarti ada hubungan yang signifikan antara daya ledak otot tungkai dengan hasil menendang bola dalam permainan sepakbola. Hal ini mengandung makna bahwa apabila permainan sepakbola memiliki daya ledak otot tungkai yang baik maka akan diikuti dengan hasil menendang bola dalam permainan sepakbola yang baik pula.

2. Ada hubungan antara panjang tungkai terhadap hasil menendang bola dalam permainan sepakbola pada mahasiswa Program Studi Pendidikan Olahraga Fakultas Keguruan dan Ilmu Pendidikan Universitas Bina Darma Palembang.

Hipotesis statistik:

$\mathrm{H}_{0}: \hat{\beta} \mathrm{x}_{1,2} \mathrm{y}=0$

$\mathrm{H}_{0}: \hat{\mathrm{p}} \mathrm{x}_{1,2} \mathrm{y} \neq 0$

Kriteria pengujian:

Jika F (Sig. > a 0,05), maka diterim $\mathrm{H}_{0}$

Jika F ( Sig. $\leq$ a 0,05 ), maka $\mathrm{H}_{0}$ ditolak dan $\mathrm{H}_{1}$ diterima.

Hasil pengujian:

Berdasarkan kriteria penguji tersebut, maka hasil analisis koefisien regresi panjang tungkai dengan hasil menendang bola dalam permainan sepakbola diperoleh nilai $\mathrm{r}=0,802(\mathrm{P}$ valube $<\mathrm{a} 0,05)$, maka diputuskan bahwa $\mathrm{H}_{1}$ diterima, berarti ada hubungan yang signifikan antara panjang tungkai dengan hasil menendang bola dalam permainan sepakbola. Hal ini mengandung makna bahwa apabila memiliki panjang tungkai yang baik maka akan diikuti dengan hasil menendang bola dalam permainan sepakbola yang baik pula.
3. Ada hubungan antara daya ledak otot tungkai dan panjang tungkai terhadap hasil menendang bola dalam permainan sepakbola pada mahasiswa Program Studi Pendidikan Olahraga Fakultas Keguruan dan Ilmu Pendidikan Universitas Bina Darma Palembang.

Hipotesis statistik

$\mathrm{H}_{0}: \hat{\rho} \mathrm{x}_{1} \mathrm{y}=0$

$\mathrm{H}_{0}: \hat{p} \mathrm{x}_{1} \mathrm{y} \neq 0$

Kriteria penguji:

Jika F ( Sig. > a 0,05), maka diterima $\mathrm{H}_{0}$

Jika F ( Sig. $\leq$ a 0,05), maka ditolak dan $\mathrm{H}_{1}$ diterima

Hasil pengujian

Berdasarkan kriteria penguji tersebut, maka hasil analisis koefisien regresi daya ledak otot tungkai, kelentukan tungkai dan panjang tungkai dengan hasil menendang bola dalam permainan sepakbola. Diperoleh nilai $r=0,939\left(P_{\text {valube }}<a 0,05\right)$, maka diputuskan bahwa $\mathrm{H}_{0}$ ditolak dan $\mathrm{H}_{1}$ diterima, berarti ada hubungan yang signifikan secara bersama antara daya ledak otot tungkai, dan panjang tungkai terhadap hasil menendang bola dalam permainan sepakbola. Hal ini bermakna bahwa, apabila memiliki daya ledak tungkai, dan panjang tungkai yang baik maka akan diikuti pula perubahan yang baik dengan perubahan hasil menendang bola dalam permainan sepakbola pada mahasiswa Program Studi Pendidikan Olahraga Fakultas Keguruan dan Ilmu Pendidikan Universitas Bina Darma Palembang.

\section{Pembahasan}

Hipotesis pertama $\mathrm{H}_{1}$ diterima yaitu, ada hubungan yang signifikan antara daya ledak otot tungkai dengan hasil menendang bola dalam permainan sepakbola pada mahasiswa Program Studi Pendidikan Olahraga Fakultas Keguruan dan Ilmu Pendidikan Universitas Bina Darma Palembang, diperoleh nila $\mathrm{r}=0,747(\mathrm{P}<\mathrm{a}$ 0,05), maka diputuskan bahwa $\mathrm{H}_{1}$ diterima, jadi hasil yang diperoleh tersebut apabila dikaitkan dengan kerangka teori berpikir maupuan teori-teori yang mendasarinya pada dasarnya hasil penelitian ini. Hal ini dijelaskan bahwa apabila Atlet memliki daya ledak yang baik maka akan baikpula dalam hasil menendang bola dalam permainan sepakbola pada mahasiswa Program Studi Pendidikan 


\section{e-ISSN: 2657-0703 dan p-ISSN: 2085-5389}

Olahraga Fakultas Keguruan dan Ilmu Pendidikan Universitas Bina Darma Palembang.

Hipotesis pertama $\mathrm{H}_{1}$ diterima yaitu, ada hubungan yang signifikan antara panjang tungkai dengan hasil menendang bola dalam permainan sepakbola pada mahasiswa Jurusan Pendidikan Kepelatihan Olahraga Fakltas Ilmu Keolahragaan Universitas Negeri Makassar, diperoleh niali $\mathrm{r}=0,802\left(\mathrm{P}_{\text {valube }}<\right.$ a 0,05$)$, maka dputuskan bahwa $\mathrm{H}_{0}$ ditolak dan $\mathrm{H}_{1}$ diterima, jadi hasil yang diperoleh tersebut apabila dikaitkan dalam kerangka berpikir maupun teori-teori yang mendasarinya pada dasarnya hasil penelitian ini. Hal ini dijelaskan bahwa apabila Atlet memiliki panjang tungkai yang baik maka akan bagus dalam kemampun tendangan jauh pada mahasiswa Program Studi Pendidikan Olahraga Fakultas Keguruan dan Ilmu Pendidikan Universitas Bina Darma Palembang.

Hipotesis pertama $\mathrm{H}_{1}$ diterima yaitu, ada hubungan yang signifikan antar daya ledak otot tungkai, kelentukan tungkai dan panjang tungkai terhadap hasil menendang bola dalam permainan sepakbola pada mahasiswa Program Studi Pendidikan Olahraga Fakultas Keguruan dan Ilmu Pendidikan Universitas Bina Darma Palembang, diperoleh nilai $\mathrm{r}=$ 0,939 ( $\mathrm{P}_{\text {valube }}<$ a 0,05 ), maka diputuskan bahwa $\mathrm{H}_{0}$ ditolak dan $\mathrm{H}_{1}$ diterima, jadi hasil yang diperoleh tersebut apabila dikaitkan dengan kerangka bepikir maupun teori-teori yang mendasarinya pada dasarnya hasil penelitian ini. Hal ini dijelaskan bahwa apabila Atlet memiliki keahlin yang baik maka akan bagus dalam hasil menendang bola dalam permainan sepakbola pada mahasiswa Jurusan Pendidikan Kepelatihan Olahraga Fakultas Ilmu Keolahragaan Univertas Negeri Makassar.

\section{SIMPULAN DAN SARAN}

Berdasarkan analisis data dan pembahasan, maka hasil penelitian ini dapat disimpulkan sebagai berikut:

1. Ada hubungan yang signifikan daya ledak otot tungkai dengan hasil menendang bola dalam permainan sepakbola. Hal ini menunjukkan bahwa daya ledak otot tungkai yang baik memberikan pengaruh yang positif terutama melakukan teknik hasil menendang bola dalam permainan sepakbola yang maksimal nila $r=0,747$, maka diputuskan bahwa $\mathrm{H}_{1}$ diterima.
2. Ada hubungan yang signifikan antara panjang tungkai dengan hasil menendang bola dalam permainan sepakbola. Hal ini menunjukkan bahwa secara maksimal memberikan pengaruh yang positif untuk melakukan gerakan kemampuan tendngan jauh dengan nilai $r=0,802$, maka diputuskan bahwa $\mathrm{H}_{1}$ diterima.

3. Ada hubungan yang signifikan antara daya ledak otot tungkai dan panjang tungkai secara besamaan dalam melakukan hasil menendang bola dalam permainan sepakbola. Hal ini menunjukkan bahwa daya ledak otot tungkai dan panjang tungkai yang baik menjadi sumber tenaga untuk kemampun tendangan jauh dapat menghasilkan kekuatan yang jauh lebih besar jika ketiga variabel tersebut digabungkan dengan nilai $r=0,939$, maka diputuskan $\mathrm{H}_{1}$ diterima.

Berdasarkan kesimpulan penelitian ini dikemukakan beberapa saran sebagai berikut:

1. Atlet : hasil penelitian ini menunjukkan bahwa unsur kemampuan fisik dalam hal ini daya ledak tungkai dan panjang tungkai memberikan hubungan yang baik dengan hasil menendang bola dalam permainan sepakbola. Untuk itu bagi Atlet agar memperhatikan kondisi fisik tersebut dalam belajar olahraga khususnya hasil menendang bola dalam permainan sepakbola.

2. Bagi Dosen atau Pelatih: dalam memberikan pengajaran pada Atlet mengenai hasil menendang bola dalam permainan sepakbola hendaknya memberikan penjelasan-penjelasan dan informasi lebih luas mengenai pentingnya memperhatikan komponen kondisi fisik daya ledak otot tungkai dan panjang tungkai.

3. Para peneliti: Diharapkan dapat melanjutkan penelian ini dengn ruang lingkup yang lebih luas, sehingga dapat menjadi informasi yang lebih lengkap bagi peneliti yang sama.

\section{DAFTAR RUJUKAN}

Bompa, O. Tudor. 1983. Theory and Methodology of Training. Dubuque: Iowa Kendall/Hunt Publising Company.

Fajar S Riesqi (2013 : 43). (Buku : Johnson B.L. \& Nelson J.K. Practical Measurements For Evaluation in PE 4th Ed. 1986). 


\section{Volume 10 Nomor 3, Oktober 2018}

Harsono. 1988. Coaching Dan Aspek Psikologi Dalam Coaching.Jakarta: Tambak Kusuma.

Irianto, Djoko Pekik. 2004. Bugar dan Sehat dengan Berolahraga. Yogyakarta: Andi Yogyakarta.

Ismaryati. 2006. Tes dan pengukuran olahraga. Solo: Penerbit dan Percetakan UNS.

Sucipto , Dkk. 2000. Sepak Bola. Depdiknas Direktorat Jendral Pendidikan Dasar Dan Menengah Bagian Proyek Penataran Guru SLTP Setara D-III.
Sukatamsi. 1984. Teknik Dasar Bermain Sepak Bola. Solo: Tiga Serangkai.

Syaefudin. 2006. Anatomi dan Fisiologi Untuk Siswa Perawat. Jakarta : Penerbit Buku Kedokteran.

Tes-Tes Health Related Fitness Gejut Weblog.Htm.

https://www.google.com/search?q=meteran

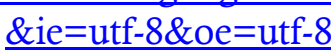

